\title{
The Institutionalization of Business Ethics of Travel Agencies in Serbia
}

\author{
Karolina Simat*, Aleksandra Dragin*, Vanja Dragićević* \\ Received: May 2012 | Accepted: July 2012
}

\begin{abstract}
The task of the paper is to point out the importance of applying regulations of legislative documents in order to achieve an appropriate level of ethical behaviour of participants in tourism. The paper also points up to the existence of the Global Code of Ethics for Tourism UNWTO. It is a basic mechanism which directs an appropriate ethical conduct of all stakeholders in tourism and requires concretization in Serbia as well. The special importance of the work is related to basic principles of ethical codes of conduction of the association of travel agencies in Great Britain (ABTA), Slovenia (ZTAS) and Bosnia and Herzegovina (UTA BiH). That kind of document still does not exist in Serbia, nor does indicate its establishment and use. Furthermore, the lack of research works focused to the issue in Serbia requires a discussion about the importance of institutionalizing business ethics in tourism. In order to address a research problem, researchers have applied different methods in each particular phase of the research process. Method used for data collection is desk research. This phase provided data from available references, while data processing was accomplished by description, examination as well as comparison.
\end{abstract}

Key words: business ethics, ethical code, travel agencies, Serbia, institutionalization

\section{Introduction}

Shawn emphasizes that in the recent few decades of the 20th century we have become aware of the disadvantages of business activity, so-called externalities. He points up that nowadays society has general interest and concern with issues related not only to rapid development, but also to quality-of-life care and environmental protection. In that sense, the purpose of social responsibility alludes business success with social responsibility to natural resources as well as resources of society (Shaw, I99I).

Numerous challenges of modern tourism market require competitive advantage and achieved goals which include more than just increased profitability. In addition, tourism as a service industry, unlike the manufacturing, requires much more qualitative and human relations. Tourism industry management requires quality relationships between business

\footnotetext{
* Department of Geography, Tourism and Hotel Management, Faculty of Science, University of Novi Sad, Trg Dositeja Obradovića 3, 21000 Novi Sad, Serbia; Corresponding author: simatka@gmail.com
} 
partners and relates to the social environment in which the industry operates as well as appropriate care for the natural environment. Such relationships are established in the rules of law, but they also have an ethical dimension.

In that sense, travel agencies are required to base their business on the principles of the code of ethics. Further concretization of these principles requests ethical awareness as well as ethical philosophy of an organization that essentially accepts the compatibility between profit and morality. All these issues resulted in an idea to write this paper with the aim of analyzing the basic documents which set out standards of business travel agencies in Serbia. The focus will be on legislative documents which impose ethical and legal aspects of travel agencies business in Serbia and conduct its control. This research points out the importance of applying the regulations of such documents in order to achieve an appropriate level of ethical conduct of participants in tourism, which is essential for efficient operation of tourism market in Serbia and its integration into the international.

\section{Literature review}

Efforts to incorporate ethics into business to attain ethical employee decision making and behaviour are not recent phenomena. The history of business ethics goes back to the origin of business, again taken in a broad sense, meaning commercial exchanges and later meaning economic systems as well. In particular, the injunctions to truthfulness and honesty or the prohibition against theft and envy are directly applicable. Sense of ethics in business is simply the application of everyday moral or ethical norms to business (De George, 1987). Although the point of right action is based on ethical principles, at the global level it gains a new meaning and greater importance. It was collaboration of ethics and economics that developed scientific discipline of business ethics in the 20th century. Academic instruction explicitly devoted to the relationship between ethics and commerce can be found in U.S. business schools as early as the first three decades of the 20th century, particularly in Catholic colleges and universities. The idea of ethics in business continues until the present day. Business ethics as an academic field emerged in the I970s. Prior to this time, there had been a handful of courses called by that name; and a few figures, such as Raymond Baumhart (Baumhart, I96I), who dealt with ethics and business. Norman Bowie dates the birth of business ethics as November 1974, with the first conference in business ethics, which was held at the University of Kansas, and which resulted in the first anthology used in the new courses that started popping up thereafter in business ethics. In 1979 three anthologies in business ethics appeared: Tom Beauchamp and Norman Bowie, Ethical Theory and Business; Thomas Donaldson and Patricia Werhane, Ethical Issues in Business: A Philosophical Approach; and Vincent Barry, Moral Issues in Business. In 1982 the first single-authored books in the field appeared: Richard De George, Business Ethics; and Manuel G. Velasquez, Business Ethics: Concepts and Cases. In recent decades this issue has been encouraged wider public interest. This is supported by a number of scientists dealing with this subject in the past three decades, who also perceive business ethics from different aspects. Among them are: Daft, 2006; Crane and Matten, 2004; Karpati, 2OOI; Trevino and Nelson, I999; Nordstrom and Ridderstral, I999; Stark, I998; Connock and Johns, I995; Shaw, I99I; Thompson et al., I990. About business ethics in terms of product quality and service speaks Fisher, 2003; Orme and Ashton, 2003; Hall, I992; Goldman, I980. Weeden (2002) recognizes the importance of ethics as the primary competitive advantage in tourism. 
It was only the beginning of the 2Ist century when issues of business ethics step-bystep took its place in Serbian literature. However, there are still a small number of authors in Serbia dealing with this topic (Subotic, 2009; Elakovic, 2008; Aleksic, 2007; Minic, 20O4; Bebek and Kolumbic, 2OO3; Rakas, 2OOI). They talk about ethics in business mainly through the philosophical debate about the concept. The lack of practical approach to the problem area may be one reason why ethics has very slow practical application in domestic companies in Serbia. Minic (2004) analyses ethical dimension of business in transition, while only some authors (Dujanic, 2003; Maric and Lekovic, 2009) perceive business ethics in the function of management. Maric and Lekovic (2009) talk about this concept in a broader context considering the impact of institutionalization of ethics in business management systems. In addition, national scientific community devotes an insignificant consideration to business ethics in tourism. Based on international literature, business ethics in tourism is usually mentioned in the context of mechanism for improving the service quality (Ajanovic, 2OIO). However, the issue of business ethics, particularly in travel agency business still hasn't got an appropriate attention. This is supported by both insufficient domestic and foreign literature on the subject, and the lack of systematic approaches to studying. Furthermore, we are very often witnesses to scandals at travel agencies in Serbia which are consequences of unethical practice in the first place. Pioneering research on the subject of business ethics, which had been done in June 2OII in tourism organizations in Novi Sad (Jovicic et al., 2OII) has promised a "new era" of scientific approach to this issue in Serbia and its practical application in the business structures of tourism industry in Serbia.

\section{The importance of institutionalizing business ethics of tourism}

The phrase "institutionalization of ethics into business" was originally developed in a corporate case study by Theodore V. Purcell and James Weber (1979), and through articles written by both researchers (Purcell, I977; Weber, I98I). According to Weber, institutionalization ethics means: “... integrating ethics into all daily decision making and work practices for all employees" (198I:47). During the next decade, the phrase "institutionalizing ethics" became a code-word and referent point for much of the applied business ethics research that followed. Institutionalization of business ethics refers to the methods that establish and maintain ethical standards of behaviour in business.

It is important to remember that tourism movements cause cultural contact and, therefore, face the ethical values of two or even more cultures. Some custom may be considered as a moral and ethical in one society at one time but wrong at another time or in another society, as people within the same society at the same time differ in their moral beliefs and standards of value. This is supported by data of the World Tourism Organization to the United Nations (UNWTO) in 2OIO. According to them, there were recorded 940 million international tourist arrivals, while revenue from international tourism recorded 9I9 billion U.S. dollars. In addition to the major impact on the global economy, it is ethnic, cultural, social, psychological and environmental dimension as well as its treatment on a variety of commercial and non-profit organizations that determines tourism as a unique phenomenon. Heterogeneity and complexity of tourism industry created a necessity of defining basic ethical principles of all stakeholders. This had resulted with the adoption of the Global Cod of Ethic for Tourism by the General Assembly of the UNWTO in Santiago in I999. Although not legally binding, the Cod features a voluntary implementation mechanism through its recogni- 
tion of the role of the World Committee on Tourism Ethics (WCTE), to which stakeholders may refer matters concerning the application and interpretation of the document. The Code's ten principles, amply cover the economic, social, cultural and environmental components of travel and tourism (www.world-tourism.org/projects/ethics/principles):

- Tourism's contribution to mutual understanding and respect between peoples and societies,

- Tourism as a vehicle for individual and collective fulfilment,

- Tourism, a factor of sustainable development,

- Tourism, a user of the cultural heritage of mankind and contributor to its enhancement,

- Tourism, a beneficial activity for host countries and communities,

- Obligations of stakeholders in tourism development,

- Right to tourism,

- Liberty of tourist movements,

- Rights of the workers and entrepreneurs in the tourism industry,

- Implementation of the principles of the Global Code of Ethics for Tourism.

The importance of the Code implementation is supported by numerous events worldwide dealing with the topic in order to draw an attention and educate many actors, including primarily public (http://ethics.unwto.org/en/event/regional-seminar-americas-ethics-andtourism; http://ethics.unwto.org/en/ethicsandtourismconference2OII).

\section{Travel agencies in Serbia and institutionalizing business ethics}

Ethical conduct of travel agencies in business activities in Serbia is based on respect of laws, regulations and other rules as well as business partnerships contracts. Law on Tourism of the Republic of Serbia (2OIO) is a fundamental document which sets out the standards of business ethics of travel agencies in Serbia.

With references to this Law, Article 2 regulates the conditions and methods of planning and development of tourism. Regulation of relations in tourism shall be based on the following principles:

I. integrated development of tourism and related activities as factors of overall economic and social development that in line with the law provides for the implementation of mutually harmonized plans and programs;

2. sustainable development of tourism as a harmonized system of technical-technological, economic and social activities based on economic development, preservation of natural and cultural goods, preservation and development of the local community;

3. enhancement of efficiency and responsibility in the use, management, protection and improvement of tourist areas;

4. provision of uniform standards for rendering services in tourism;

5. protection of the national economy, beneficiaries of tourist products and tourist professions;

6. partnership relation between the private and public sectors and civil society in planning, shaping and marketing of tourist products;

7. provision of uniform, public and electronic records of registered and recorded data in the field of tourism. 
It can be concluded that the regulation of relations in tourism in Serbia is modelled on the principles of the Global Code of Ethics.

Activities that travel agency could perform are defined in Article 45. Article 56 as well as Article 57 relates to the rights and obligations of the tour operators and passengers, while Article 58 defines the obligations of intermediary that offers and sells tourist travels of the travel organizer.

The application of the provisions of this Law and regulations adopted based on this Law are supervised by the Ministry and tourism inspectors. According to Article I2O, when performing the inspection supervision, the tourist inspector have the right and duty to check whether the prescribed conditions for conducting activities and rendering services regulated by this Law are met, verify the identity of persons employed in business companies, as well as persons conducting activities and providing services regulated by this Law, inspect the premises in which the activities are conducted and services rendered, as well as contracts, records and other documents required for verifying the legality of operation of business companies. The tourist inspector is authorized to sanction unethical behaviour in business activities of travel agencies. That is to say, he is authorized to temporarily ban the performance of activities referred to Article 43 of this Law or to impose a fine on the spot to following: the travel agency that operates without a license or does not meet any more the conditions upon which the license was issued; the travel agency that offers and sells travel arrangements of travel organizer which has not concluded an intermediary travel contract; the agency that does not determine the general conditions of travel and travel program in writing in accordance with the Law on Tourism and the law of obligations; the agency that does not deliver to passengers directly or electronically general conditions of travel and itinerary with the proof of travel; and agency which fails to comply with established general conditions of travel and itinerary.

Doing business in accordance with the Law regulations of tourism industry meets minimum standards of responsible behaviour of tourism participants. As a business entity, travel agency also acts on Serbian market in accordance with other legislative documents such as Law on protection of competition, Consumer protection act, Anti-discrimination law, Law on prevention of abuse at work, Health and safety at work act, Law on environmental protection and others.

Unethical business of travel agencies is usually manifested due to practice which is not consistent with regulations of the Consumer Protection Act. This Act regulates the fundamental rights of the consumers, conditions as well as means of consumer protection. According to the new Law on Consumer Protection and the Law on tourism, which came into force on I January 2OII, if the agency does not reimburse passengers for a failure of agency, the state will be forced to use insurance policy and pay for the damages. According to Article IO5 Consumer Protection Act (http://www.zapotrosace.rs/CMS/download/law-on-consumerprotection-republic-of-serbia.pdf), if the traveller terminates the contract due to breach of conduct, the agency shall bear the costs of its return. If the journey is not in accordance with agreed, the customer may demand deficiency compensation or terminate the contract. The Agency should provide a money-back guarantee and pay the costs of customers return if the service from contract was not provided.

Implementation of the Law on Tourism, with the other aforementioned legislation and action in accordance with their terms is a powerful tool for guiding travel agencies conduct to ethical and social responsibility. However, practice has shown that all these regulations are not sufficient to accept the importance of ethical and responsible conduct. This is sup- 
ported by numerous scandals of travel agencies based on unethical practices in the first place, through a variety of consumer's as well as business partner's fraud. In 2010 inspectors of Sector for Tourism Inspection (Serbian Government, Ministry for Economy and Regional Development) received 452 applications of citizens against travel agencies in Serbia. Inspectors found that $2 \mathrm{IO}$ or $46 \%$ of complaints were established (http://www.turizamzavasinas. com/sr/aktuelno/na-sta-su-se-turisti-zalili-2OIO/\#). Based on the figures we can conclude that laws prescribe only minimum standards for ethical practice. In one hand, they do not sufficiently raise the awareness of business actors involved in tourism industry about the importance of accepting responsibility and ethical conduct that would contribute to better business partnerships. On the other hand, consumers in Serbia (in this case they are tourists) are not sufficiently aware of their rights, particularly in terms of protection or redress.

In order to advocate common interest related to the products and services offered by travel agencies, their business activities, as well as all aspects of tourism industry, the National Association of Travel Agencies is established. It is produced as a result of social pooling of certain organizations at a time when agencies become aware of all the benefits of joint disposal of tourism products in order to meet basic tourism principles. Such public appearances include all efforts with the purpose of creating a high-quality tourist product in the country, based on the economic interests of all the participants engaged in creating and placing the tourist supply on the market. The existence of such national associations is usual in almost all developed tourist markets which protect domestic tourism economics as well as regional economics.

On the territory of Serbia operates the National Association of Travel Agencies (YUTA). It was founded in 1954 under the name Yugoslav Association of Travel Agencies, as a consequence of the strong development of agency business in the former Yugoslavia. According to available data, it can be concluded that most travel agencies in Serbia, almost four hundred of them, are YUTA members and they perform over 95\% of organized domestic and foreign tourist trade. The main purpose of the Association imposes itself - joint participation on tourism market. Such organized tourism association works easier than a separate travel agency. Competitiveness in tourism business is always on the side of these organizations.

On the basis of the Article 37 of YUTA Statute and Article 56 of Law on Tourism ("Official Gazette of the Republic of Serbia” 36/2009 and 88/2OIO), the Steering Committee has determined general requirements for travel for YUTA members related to:

- Pre-contractual notification,

- Registration, payment and contract,

- Obligations and rights of the organizers,

- Obligations and rights of passengers,

- Price and content of the travel programs,

- Changing of prices and passengers right to cancellation,

- Categorization and services description,

- Accommodation, meals and transfer,

- Passports, health and law regulations,

- Luggage,

- Cancellation and Changing travel program by organizers,

- Cancelling travel arrangements by the passengers,

- Travel insurance and guarantees,

- Help, objection, accusation and dispute resolution,

- Individual program and services "on request", 
- Protection of passengers personal data and

- Obligingness of acting.

Travel agencies exhibit ethical conduct in business activities throughout conscientious acting according to the general terms of travel. However, modern business requires developing better business partnerships and relationships of social environment, as well as appropriate care for the natural environment.

\section{Discussion}

World Committee on Tourism Ethics translated the Global Cod of Ethic for Tourism in 46 languages, including the Serbian (http://ethics.unwto.org/en/content/full-text-global-codeethics-tourism). However, this code has not yet come in such form to travel agencies in Serbia as a recommendation from the competent ministries of the Republic of Serbia or any other body. Furthermore, national data related to the ethical and social dimension of tourism are still not available on the official site of the UNWTO, in contrast to many developed as well as developing countries (http://ethics.unwto.org/en/country-ethics).

Many associations in the world related to the National Association of Tourist Agencies in Serbia have a code of business ethics and rules that their members, agencies and tour operators, committed to professional practice and consumer protection - tourists protection. For example, the primary aims of the Code of Conduct of ABTA (The Association of British Travel Agents) are to ensure that the public receive the best possible service from members, and to maintain and enhance the reputation, good name and standing of ABTA and its members. It's essentially a guide to good practice, although some of what it contains is also required under UK and European law (http://www.abta.com/about/industry_standards).

Slovenia and Serbia used to be one country twenty years ago, former Yugoslavia, and Slovenia is now a member of the European Union. There acts Association of Tourist Agencies of Slovenia (ZTAS - Združenje turističnih agencij Slovenije), which also for its members prescribes business and ethical rules through the Code of Business Conduct and Ethics.

In Bosnia and Herzegovina, also former Yugoslav republic, extremely complex code of business ethics is provided by Statute UTA BiH (Association of Tourist Agencies of Bosnia and Herzegovina), an association that was also created in the tradition of the former Yugoslav Association of Tourist Agencies. It consists of 50 articles (http://www.uta.ba/index. php?option=com_content\&view=article\&id=I87:kodeks-poslovne-etike\&catid=3:0-nama).

In order to accept the importance of responsible and ethical conduct as well as to effective function of tourism market in Serbia and its integration into the international, it is necessary to establish and use codes of business ethics for members of the National Association of Tourist Agencies in Serbia, which could be modelled or based on the codes of the aforementioned related associations in other states.

Existence of a number of separate regulations (primarily laws) that are related to business ethics in tourism proof that Serbia has recognized the importance of responsible conduct of employees in travel agencies. However, the absence of the Global Code of Ethics for Tourism in practice is confusing, because each actor had to cope in a variety of data, rather than having available one complete document (Dragin, 2OII).

The Code should give basic guidelines of ethical conduct in business activities of members of the National Association of Travel Agencies in Serbia. The Code would contribute to 
more transparent and more effective operations and better relations between members of the Association and the social environment in which they are operating, setting balanced ethical criteria between various rights and obligations of all participants. Certainly, it should be advisable that members of the Association, in accordance with their needs, more specifically develop its own ethical issues and ethical principles of the Code. The main areas of member's activity, which need to be prescribed by the Code, modelled on UTA and ZTAS code of conducts, are:

- Internal relations in a business office,

- Quality and care for the environment,

- Relationships with owners,

- Relationships with customers,

- Relationships with suppliers,

- Relationships with competitors,

- Relationships toward business debt and demand,

- Relationships with state bodies and public,

- Donations and sponsorships,

- Adoption and implementation of the Code,

- The procedures for violations of the Code,

- Correction, education and other measures.

Because the Code is voluntary, it is necessary to ensure that all companies joined the National Association of Travel Agencies YUTA, as well as their branches in Serbia and abroad, commit themselves to its principles and goals and take practical measures to implement them. It is necessary that the managing board of the Association form a special monitoring commission on the Code implementation. In case of proven violations of the Code of conduct, the competent authorities of the Association are recommended to take corrective, educational and other measures to penalize business entities and responsible persons. Corrective actions to agencies include the obligation of public apology and business coordination with the regulations of the Code. Educational measures that may be conducted include the obligation to provide advises as well as educational programs under the articles of the Code. It is also possible to implement the following measures: a public warning with publication in the press, radio or television, a prohibition on participation in trade fairs which are organized by the Association, and even upon recommendation by the Membership Committee losing membership status of the Association.

In accordance with needs and possibilities, it is recommended that travel agencies provide employee training that will encourage the Code application and avoid punishment for unethical business conduct.

\section{Conclusion}

Ethical conduct of travel agencies in business activities in Serbia is based on respect of the Law on tourism, YUTA standards (general business conditions for its members), regulations and other rules. Moreover, ethical conduct is based on fulfilment of contracts which are made between business partners, tour operators, brokers or transportation companies.

Although Serbia is still a membership candidate for UNWTO, travel agencies, as the representative of heterogeneous structure of tourism industry, have big challenge ahead if tour- 
ist market of Serbia intend to join international market. In order to survive as economic entities, they have not only to earn a profit, but also must coordinate their operations with law and social values. It increases the need for considering an ethical approach to travel agencies business in Serbia, adoption and implementation of generally accepted principles, codes of ethics which will control relations of the opposed moral values of different societies and socio-cultural consequences that result from them.

General principles of the Global Code of Ethics in Tourism require further concretization to ensure corporate social responsibility. In other words it is not only corporation responsibility and impact on social and business environment where travel agencies operate (do business), but also customer satisfaction and social welfare. Some authors emphasize the necessity for open public dialogue that should determine basic ethical guidelines to promote decision-making to the benefit of both economic subjects and the community in general. This is achieved in Serbia by closer regulation of rights, obligations and responsibilities of the relevant laws and accompanying regulations codified business practices (common practices), mostly on the national level.

Considering the way of determination the guidelines of ethical conduct by the World Tourism Organization and other international tourism organizations and associations, and taking into account the lack of such regulations in Serbia, it can be concluded that, above all, it is necessary not only to adopt such standards in written form, but also to provide their application. The first steps of their appliance should be training of employees of travel agencies.

Implementation of the Code would be more effectively achieved when Government was able to incorporate its principles and goals into national travel policies and legislation. To ensure that there is support for these policies and legislative changes, Government should take steps to consult with industry and other groups to promote their support and voluntary compliance.

Ministry of Economy and Regional Development of the Republic of Serbia, Sector for Tourism, as a competent body, should give an attention to the issues of rules and regulations of ethical conduct in tourist activity, as well as solid system of sanctions directed primarily to the consumer (tourists), action against corruption and unfair competition. In addition, Government should encourage travel communities and industry to develop codes of good practice that are consistent with, and support, the goals and purpose of the UNWTO Code of Conduct. These codes of good practice are another important way of promoting the implementation of the Code. It would raise awareness of business stakeholders in tourism industry about the significance of accepting responsible and ethical business conduct of travel agencies as an indispensable prerequisite for efficient market operation and an integration of the Serbian travel market into the international.

Implementing ethical business conduct would probably raise or affect positively service quality of travel agencies in Serbia, from consumers' perspective, but also, from travel agencies' business partners perspective. Also, it might affect loyalty of clients and business partners, as well as the image of travel agency in a broader sense. As tourist in Serbia, as well as in whole world, become more aware of its rights and travel agencies' obligations related to travel arrangements, implementing ethical business conduct will become a must for travel agencies business and will represent a competitive advantage of travel agency on a highly competitive tourism market. All these issues might represent implications for future researches, in order to raise the awareness on the importance of implementing ethical code in travel agencies and other specifically service enterprises. 


\section{References}

Ajanovic, E. (2OIO). The principles of operation and quality of travel guiding, Bachelor thesis, Faculty of Tourism and Hotel Management, Singidunum University, Belgrade.

Aleksic, A. (2007). Business Ethics - an element of successful business, The Proceedings of Zagreb Faculty of Economics and Business, Vol. 5 (August), 6-8.

Barry, V. (1979). Moral Issues in Business, Belmont, Calif.: Wadsworth.

Baumhart, R.C. (I96I). How ethical are businessmen?, Harvard Business Review, 39 (4).

Beauchamp, T. and Norman B. (200I). Ethical Theory and Business, Englewood Cliffs, NJ: Prentice-Hall, I979, 6th edition.

Bebek, B. and Kolumbic, A. (2003). Business Ethics, Sinergy.

Connock, S. and Johns, T. (I995). Ethical Leadership, IPD, London.

Crane, A. and Matten, D. (2004). Business Ethics: A European Perspective, Oxford University Press, New York.

Daft, R. L. (2004). Organization Theory and Design, Thompson South-Western, Ohio.

Daft, R. L. (2006). The New Era of Management, International Edition, Thompson SouthWestern, China.

De George, (2003). Business Ethics, Belgrade.

De George, T. R. (1987). The Status of Business Ethics: Past and Future, Journal of Business Ethics, 6, Springer Science+Business Media.

De George, T. R. (1999). Business Ethics, N.Y.: Macmillan, I982, 5th edition, Prentice-Hall.

Donaldson, T. and Werhane, P. (20O2). Ethical Issues in Business: A Philosophical Approach, Englewood Cliffs, NJ: Prentice-Hall, 1979, 7th edition.

Dragin, A. S. (2OII). Tourism and business ethics, material from lectures, University of Novi Sad, Faculty of Sciences, Department of Geography, Tourism and Hotel Management, Novi Sad.

Drummond, J. and Bain, B. (2OOI). Business Ethics, Clio, Belgrade.

Dujanic, M. (2003). Business ethics in the function of management, Proceedings of Rijeka Faculty of Economics: Journal of Economics and Business 2I(I).

Elakovic, S. (2008). Business ethics and communication, Singidunum University, Belgrade.

Fisher, J. (20O3). Surface and deep approaches to business ethics; Leadership \& Organization Development Journal 24(2), 96-IOI.

Goldman H. A. (I980). The Moral Foundations of Professional Ethics, NJ: Rowan \& Littlefield, Totowa.

Group by UNWTO (2007). 2008 International Recommendations for Tourism Statistics, New York/Madrid.

Hall, J. S. (I992). The Emergence of Ethics in Quality, Ethics in Hospitality management, book of Readings Education Institute of American Hotel \& Motel Association, East Lansing, Michigan.

Johannesen L. R. (1990). Ethics in Human Communication, Third edition, Prospect Heights, IL: Waveland.

Jovicic, A., Pivac, T. and Dragin, A. (2OII). Ethical Conduct of Employees in Tourist Organizations in Novi Sad (Serbia), Turizam I5(4), I35-I47.

Karpati, T. (I983). Business Ethics, Graphics, Osijek.

Law on tourism (2009). Official Gazette of the Republic of Serbia 36/2009.

Law on tourism (2OIO). Official Gazette of the Republic of Serbia 88/2OIO.

Maric, S. and Lekovic, B. (2009). Institutionalizing ethics and influence on the management of business system, Annals of the Faculty of Economics in Subotica vol. 22, 53-59. 
Minic, V. (2004). Ethical dimension of doing business in transitional processes, Sociological review 38 (I-2), IOI-II3.

Minic, V. (20O4). Relationship between business ethics and social values, Collected Papers - SymOrg, Faculty of Organizational Sciences, Belgrade.

Nordstrom, K.A. and Ridderstrale, J. (1999). Funky Business, Talent makes capital dance, Bookhouse Publishing, Stockholm.

Norman E. Bowie (1986). "Business Ethics," in New Directions in Ethics, ed. Joseph P. DeMarco and Richard M. Fox, New York: Routledge \& Kegan Paul.

Orme, G. and Ashton, C. (20O3). Ethics - a foundation competency, Industrial and Commercial Training 35(5), I84-190.

Purcell T. V. and Weber, J. (I979). Institutionalizing Corporate Ethics: A Case History (New York: Presidents Association, Chief Executive Officers' Division of the American Management Association.

Rakas, S. (2OOI). Introduction to Business Ethics, Belgrade

Ristic, D. (2004). Fundamentals of management, Faculty of management, Novi Sad.

Shaw, W.H. (I99I). Business Ethics, Wadsworth Inc., Belmont.

Stark, A. (1998). What's the Matter with Business Ethics?, Harvard Business Review, MayJune, pp. 3.

Takala, T. (2006). Editorial: An ethical enterprise - What is it?, Electronic Journal of Business Ethics and Organiyation Studies II(I), 4.

Trevino, L.K. and Nelson, K. (I999). Managing Business Ethics: Straight Talk about How to Do It Right, John Wiley \& Sons Inc., New York.

Velasquez, M. G. (20O2). Business Ethics: Concepts and Cases, Englewood Cliffs, NJ: Prentice-Hall.

Walton, C. (1967). Corporate Social Responsibilities, Belmont, CA: Wadsworth Publishing Co.

Weber, J. (198I). Institutionalizing Ethics into the Corporation, MSU Business Topics, 47-52.

Weber, J. (1993). Institutionalizing Ethics into Business Organizations: A Model and Research Agenda, Business Ethics Quarterly 3(4), 4I9-436.

Weeden, C. (2OO2). Ethical Tourism: An opportunity for competitive advantage, Journal of Vacation Marketing, London.

http://abta.com/about/industry_standards

http://ethics.unwto.org/en/content/full-text-global-code-ethics-tourism

http://ethics.unwto.org/en/country-ethics

http://ethics.unwto.org/en/ethicsandtourismconference2OII

http://ethics.unwto.org/en/event/regional-seminar-americas-ethics-and-tourism

http://statistics.unwto.org

http://uta.ba/index.php?option=com_content\&view=article\&id=I87:kodeks-poslovneetike\&catid=3:0-namahttp://ztas.org

http://world-tourism.org/projects/ethics/principles

http://www.turizam.merr.gov.rs

http://www.turizamzavasinas.com/sr/aktuelno/na-sta-su-se-turisti-zalili-2OIO/\#

http://www.uta.ba/index.php?option=com_content\&view=article\&id=I87:kodeksposlovne-etike\&catid=3:0-nama

http://www.yuta.rs/sr/yuta/uslovi.asp

http://www.zapotrosace.rs/CMS/download/law-on-consumer-protection-republic-of-serbia.pdf 